\title{
Occurence of antibiotic resistant bacteria in raw cow milk from vending machines
}

\author{
Monika Krahulcová, Kristína Lépesová, Lucia Bírošová \\ Institute of Food Science and Nutrition, \\ Faculty of Chemical and Food Technology, STU in Bratislava, \\ Radlinského 9, 81237 Bratislava, Slovak Republic \\ lucia.birosova@stuba.sk
}

\begin{abstract}
The prevalence of antibiotic resistant coliform bacteria and enterococci in fresh raw cow milk obtained from four vending machines in Slovakia was assessed. Also, differences in the number of antibiotic-resistant bacteria in milk according to season (winter and summer) were compared. Number of total coliform bacteria ranged from 2.45 to $4.18 \log \mathrm{CFU} / \mathrm{mL}$. Majority of them were resistant to ampicillin. This was expected due to their intrinsic resistance apart from Escherichia coli which is sensitive to ampicillin. In addition, we observed also tetracycline and gentamicin resistance. Each of our samples contained E.coli. Number of total enterococci ranged from 1.95 to $3.78 \log \mathrm{CFU} / \mathrm{mL}$. We have observed predominantly vancomycin resistance in all tested samples. In samples taken during winter we have found higher number of total and resistant coliforms as well as total enterococci compared to those taken during summer.
\end{abstract}

Key words: antibiotic resistance, coliforms, enterococci, raw milk

\section{Introduction}

Milk represents a highly nutritious foodstuff which can be obtained from different animal sources. Due to its high nutritional content including proteins, fats, carbohydrates, vitamins, minerals and essential amino acids, it can easily undergo microbial contamination (Quigley et al., 2013). These microorganisms can generally enter milk from three main sources such as; within udder, exterior of the udder and the surface of milk handling and storage equipment (De Silva et al., 2016). This contaminating microbiota is composed of food-borne pathogens, spoilage and commensal bacteria. Common microbiota includes enterobacteria, enterococci, streptococci, staphylococci, bacilli, clostridia, coryneform bacteria and collection of anaerobic bacteria such as propionic bacteria, lactobacilli, bifidobacteria or leuconostoc (Teuber and Perreten, 2000). Composition of milk microbiota is changing according to season, farm hygiene, feed and housing of cows (Ellis et al., 2007). Dairy cow cleanliness is influenced by housing strategy as cows became dirtier in the transition from summer grazing to winter housing, and this was especially true for cows on conventional farms. Cleanliness is determined using a validated scoring system, with four anatomical areas considered: the flanks, the hind legs, the whole tail and the udder. Knowing that soiling of the udder and teats is one of the most important contamination sources of milk. Cows producing large quantities of loose faeces are generally dirtier than cows producing firm faeces. This faecal consistency in turn reflects cow nutrition and digestion, adding extra support to the hypothesis that feed strategy might influence the microbial milk quality, not only by composition of the feed but also by its influence on faecal consistency (Coorevits et al., 2008). Presence of food-borne pathogens represents the main risk for consumers. Another challenge is the nature of antibiotic-resistant bacteria as well as antibiotic resistance genes and their possible transfer from one bacterium to another. Bacteria with such potential include common contaminants like enterobacteria, enterococci, coagulase negative staphylococci and lactobacilli (Teuber and Perreten, 2000).

Alongside pasteurized milk, there was and still is a high consumer demand for raw milk (Valík etal., 2009; Bianchi et al., 2013). However, raw milk consumption is accompanied by the risk of ingesting pathogenic bacteria that can pose an elevated health hazard (Latorre et al., 2009). Although zoonotic diseases like brucellosis and tuberculosis have been or are nearly completely eradicated in European Union countries (EFSA, 2010), the milk of asymptomatic animals may harbour other infectious agents: milk pasteurization was, and remains, crucial to preventing milk-borne zoonosis. Since 1999, thermally untreated raw milk is available for Slovak consumers in small amounts directly on farms or via automatic self-service vending machines (Valík, 2013). European regulations, and the Regulation EC 853/2004 in particular, allow the sale of raw milk, defining it as "the secretion of the mammary gland of farmed animals that has not been heated to more than $40{ }^{\circ} \mathrm{C}$ or undergone any treatment that has an equivalent effect”. This regulation sets forth the guidelines for raw milk sale and distribution on the market. However, our previous 
data (Valík et al., 2009) showed that number of faecal indicators found in raw milk from vending machines significantly exceeded limits; heat treatment of such milk is necessary. It is evident that this microbial contamination can endanger consumer's health especially of children or immune-compromised persons. Moreover, if antibiotic resistant bacteria are present in such foodstuff, this problem generates an ecological dimension which goes far beyond the common concept of the definition of a food-borne pathogen (Teuber and Perreten, 2000).

The object of our work was monitoring of antibiotic resistant coliforms and enterococci prevalence in raw cow milk obtained from vending machines in Slovakia.

\section{Material and methods}

\section{Characterization of sampling sites}

Samples of fresh raw milk were obtained from three vending machines (Petržalka, Karlova Ves, Dúbravka) situated in capital city Bratislava in winter season (February-March 2017). Second sampling was realized in summer (August-September 2017). At this time the vending machine Petržalka was out of order, so a sample from vending machine in Liptovký Mikuláš was obtained. Vending machine Petržalka and Dúbravka collected milk from Javorinka grange in Galanta, Karlova Ves collected milk from Lozorno grange and Liptovský Mikuláš from the farm Kriván̆. All vending machines documented that temperature of milk was $4-8{ }^{\circ} \mathrm{C}$ and milk was filled into machine at the sampling day. Samples were collected in sterile cold tubes and transferred in the fridge box into the laboratory for microbiological assessment.

\section{Detection of antibiotic resistant bacteria}

Bacteria were detected according to study Mackulak et al. (2016) with slight modifications. Briefly, samples of fresh raw milk were obtained from vending machine in sterile tube and transferred in fridge box to laboratory. Aliquots of samples $(0.1 \mathrm{~mL})$ from each vending machine were spread on selective diagnostic agar plates. The counts of total coliforms were determined on chromogenic Chromocult coliform agar (Merck,
Darmstadt, Germany) and enterococci were determined on Slanetz-Bartley agar (Sigma-Aldrich, St. Louis, USA). Antibiotic resistant strains were detected after cultivation on plates containing diagnostic media with different antibiotics. Before bacteriological counting, plates with coliform bacteria were incubated for $24 \mathrm{~h}$ at $37^{\circ} \mathrm{C}$ and enterococci for $42 \mathrm{~h}$ at $42{ }^{\circ} \mathrm{C}$. Each experiment ran in triplicate and was repeated two times. Applied antibiotics (ampicillin, ciprofloxacin, gentamicin, chloramphenicol, tetracycline, and vancomycin) were purchased from Sigma-Aldrich (Germany). Antibiotic resistance was detected according to European (EUCAST) as well as to US (CLSI) resistance breakpoints.

\section{Results and discussion}

Raw milk contains a wide range of pathogenic bacteria and many of them are responsible for causing outbreaks of food-borne illnesess all over the world (do Carmo, 2002; Jorgensen et al., 2005; Oliver et al., 2009; Food standards Australia New Zealand, 2009). Even though enhanced nutritional qualities, taste and health benefits have all been advocated as reason for increased interest in raw milk consumption (Oliver et al., 2009). Faecal indicators such as coliform bacteria and enterococci are very frequent in raw milk and according to their potential pathogenicity they can cause severe health problems (Food standards Australia New Zealand, 2009).

Number of total coliform bacteria in samples of raw cow milk ranged from 2.45 to $4.18 \mathrm{log}$ $\mathrm{CFU} / \mathrm{mL}$ (Tab. 1). Escherichia coli were observed in all samples from 1.57 to $2.72 \log \mathrm{CFU} / \mathrm{mL}$. The highest number was observed in the sample from wending machine in Petržalka in winter and from Liptovský Mikuláš in summer. This could be caused by location of production in the case of Liptovský Mikuláš. The area in northwest of Slovakia is more focused on traditions and natural ways of farming compared to southwest. On the other hand, results from Petržalka were surprising, according to the farm of origin, which was the same as in the case of vending machine from Dúbravka. Generally, raw milk from Dúbravka

Tab. 1. Number of total monitored bacteria in samples of raw milk (log CFU/mL).

\begin{tabular}{lcccccc}
\hline \multirow{2}{*}{ Microorganism } & \multicolumn{2}{c}{ Winter milk } & \multicolumn{3}{c}{ Summer milk } \\
\cline { 2 - 6 } & Karlova Ves & Dúbravka & Petržalka & Karlova Ves & Dúbravka & Liptovský Mikuláš \\
\hline coliform bacteria & 3,98 & 3,73 & 4,12 & 2,76 & 2,45 & 4,18 \\
Escherichia coli & 2,11 & 1,57 & 2,38 & 1,85 & 1,70 & 2,72 \\
enterococci & 2,51 & 3,78 & 3,41 & 2,26 & 3,95 \\
\hline
\end{tabular}


possessed the lowest number of total bacteria, except enterococci in winter. This difference may be caused by lower maintenance of vending machine in Petržalka, which was subsequently closed and we could not reach the summer sample from this machine. European Union as well as Slovakia does not have microbiological criteria for coliforms in raw milk. It is the outcome of the fact that raw milk is not intended for direct consumption. If we take a look at the limits $\left(10^{3}\right.$ coliforms CFU/mL, 100 E.coli $\mathrm{CFU} / \mathrm{mL}$ ) given by New Zealand Food Safety Authority, only two samples of summer milk (Karlova Ves and Dúbravka) satisfy these limits.

\section{Occurence of antibiotic resistant coliform bacteria in raw milk}

Resistance to ampicillin, gentamicin, ciprofloxacin, tetracycline and chloramphenicol was tested. Antibiotics were chosen as representants of different antibiotic classes. Concentrations of antibiotics were selected according to the resistance breakpoints given by European Comitee on Antimicrobial Susceptibility testing (EUCAST) for EU and by Clinical Laboratory Standards Institute (CLSI) for US. Majority of detected coliform bacteria were ampicillin-resistant (Tab. 2). This is due to their intrinsic resistance to this antibiotic apart from E.coli which is sensitive to this antibiotic (Tab. 3). In winter milk from Petržalka wending machine, we have observed resistant coliforms to all tested antibiotics. The best results were detected in summer milk from machine in Dúbravka. Generally, summer milk possesses lower prevalence of antibiotic resistant coliforms compared to winter milk. In four samples we have registered tetracycline-resistant bacteria. This could be caused by frequent application of oxytetracycline in the Slovak Republic as an intramammary infusion of Oxymykoin to dairy cows with mastitis (Jevinova et al., 2003).

Ampicillin-resistant E.coli was found in almost all samples except winter milk from wending machine

Tab. 2. Number of antibiotic resistant coliform bacteria in samples of raw milk $(\log \mathrm{CFU} / \mathrm{mL})$.

\begin{tabular}{lccccccc}
\hline \multirow{2}{*}{ Antibiotic } & $\begin{array}{c}\text { Resistance } \\
\text { breakpoints }\end{array}$ & Winter milk & \multicolumn{5}{c}{ Summer milk } \\
\cline { 3 - 7 } & Karlova Ves & Dúbravka & Petržalka & Karlova Ves & Dúbravka & Liptovský Mikuláš \\
\hline \multirow{2}{*}{ AMP } & EU & 3,87 & 2,18 & 3,99 & 2,59 & 2,26 & 4,14 \\
& US & 3,08 & 1,81 & 3,95 & 2,49 & 2,23 & 4,06 \\
& EU & 2,93 & 1,30 & 3,13 & ND & ND & ND \\
GIP & US & 1,60 & ND & 2,60 & ND & ND & ND \\
& EU & ND & ND & 3,25 & ND & ND & ND \\
CH & US & ND & ND & 2,20 & ND & ND & ND \\
& EU & ND & 1,90 & 3,42 & ND & ND & ND \\
TET & US & ND & 1,41 & 2,45 & ND & ND & ND \\
& EU & ND & 1,72 & 3,91 & 1,00 & ND & 2,18 \\
\hline
\end{tabular}

AMP - ampicillin, GEN - gentamicin, CIP - ciprofloxacin, CH - chloramphenicol, TET - tetracycline, ND - not detected, EU - resistance breakpoints given by EUCAST, US - resistance breakpoints by CLSI.

Tab. 3. Number of antibiotic resistant Escherichia coli in samples of raw milk $(\log \mathrm{CFU} / \mathrm{mL})$.

\begin{tabular}{lccccccc}
\hline \multirow{2}{*}{ Antibiotic } & $\begin{array}{c}\text { Resistance } \\
\text { breakpoints }\end{array}$ & Winter milk & \multicolumn{5}{c}{ Summer milk } \\
\cline { 3 - 8 } AMP & Karlova Ves & Dúbravka & Petržalka & Karlova Ves & Dúbravka & Liptovský Mikuláš \\
\hline \multirow{4}{*}{ GEN } & 1,90 & ND & 2,30 & 1,70 & 1,48 & 2,69 \\
& US & 1,60 & ND & 1,90 & 1,66 & 1,48 & 2,54 \\
CIP & EU & ND & ND & ND & ND & ND & 1,48 \\
& US & ND & ND & ND & ND & ND & ND \\
CH & EU & ND & ND & ND & ND & ND & ND \\
& US & ND & ND & ND & ND & ND & ND \\
\multirow{2}{*}{ TET } & EU & ND & ND & ND & ND & ND & ND \\
& US & ND & ND & ND & ND & ND & ND \\
\hline
\end{tabular}

AMP - ampicillin, GEN - gentamicin, CIP - ciprofloxacin, CH - chloramphenicol, TET - tetracycline, ND - not detected, EU - resistance breakpoints given by EUCAST, US - resistance breakpoints by CLSI. 
Tab. 4. Number of enterococci growing on selected antibiotics in sample of raw milk $(\log \mathrm{CFU} / \mathrm{mL})$.

\begin{tabular}{lcccccc}
\hline \multirow{2}{*}{ Antibiotic } & Winter milk & \multicolumn{5}{c}{ Summer milk } \\
\cline { 2 - 7 } & Karlova Ves & Dúbravka & Petržalka & Karlova Ves & Dúbravka & Liptovský Mikuláš \\
\hline AMP & ND & ND & 2,94 & 2,11 & 1,90 & 1,90 \\
GEN & ND & ND & ND & ND & ND & ND \\
CIP & ND & ND & ND & 1,00 & 1,00 & 1,30 \\
VAN & 1,90 & 2,90 & 2,30 & 1,78 & 1,00 & 2,04 \\
\hline
\end{tabular}

AMP - ampicillin, GEN - gentamicin, CIP - ciprofloxacin, VAN - vancomycin, ND - not detected.

in Dúbravka (Tab. 3). This sample possessed no antibiotic resistant E.coli. Occurrence of ampicillin resistant bacteria may be due to frequent use of this antibiotic in human medicine for treatment of coliform infections (Solomakos et al., 2009). In one case we have recorded resistance to gentamicin. In food, E.coli can be present in both pathogenic and saprophytic populations with different roles. The importance of E.coli as a cause of diseases has been increasing in the EU since 2008 and was further strengthened because of large outbreak in Germany in the summer of 2011 (Ačai et al., 2015).

\section{Occurence of antibiotic resistant enterococci in raw milk}

Enterococci are the causative agents of certain infectious diseases, including urinary tract inflammation or endocarditis. These bacteria are found regularly in raw milk. Originating in intestinal tracts of animals, these bacteria are thermoresistant, i.e. they can survive the pasterization conditions in small numbers. Subsequently, under suitable growth conditions, they can multiply to high counts (Teuber and Perreten, 2000). Number of total enterococci in samples of raw cow milk from automatic vending machines ranged from 1.95 to $3.78 \log \mathrm{CFU} / \mathrm{mL}$ (Tab. 1). Resistance to ampicillin, gentamicin, ciprofloxacin and vancomycin was tested. In this case, we have applied only resistance breakpoints given by EUCAST. In all samples of raw milk we have observed vancomycin resistant enterococci (Tab. 4). Vancomycin resistance in enterococci, which is conferred by several genes, is a major cause of concern due to the limited therapeutic options for treating infections with these organisms (Jung et al., 2007). Importance of these strains is highlighted also by WHO list of pathogens with critical priority. None of the tested raw milk contained enterococci resistant to gentamicin. The new dimension of the enterococci in food, as well as in medicine, is their role as a genetic turn-table for antibiotic resistance genes. Antibiotic resistant enterococci prevailed especially in summer milk compared to winter samples. Best results were observed in winter samples from Karlova Ves and Dúbravka, which contained only vancomycinresistant strains.

\section{Conclusion}

Emergence of antibiotic resistance in bacteria represents an enormous health and socio-economic problem worldwide and, unfortunately, is still on rise. It is caused by inaproppropriate and extensive use of antibiotics in human and veterinary medicine but also because of practices in the agricultural industry. Antibiotic resistant bacteria from agricultural environments such as food of animal origin like unprocessed raw milk can be transmitted to humans, in whom they cause disease that cannot be treated by conventional antibiotics. In recent years, more and more consumers in Slovakia started to prefer unprocessed raw milk due to its nutritional quality. This consumer call resulted in setting up of automatic vending machines providing raw milk. However, this milk is not thermally processed, from hygienic point of view; it is needed to boil it before consummation. Unfortunately, notall people respect this important warning, resulting in occurrence of food-borne diseases or their outbreaks. Our data show, that raw milk offered in automatic vending machines obtain coliform bacteria and enterococci resistant to antibiotics. However, resistant strains may lead to development of untreatable or hardly treatable illnesses; health risk of unprocessed milk is much higher. Other important threat of raw milk consumation is that antibiotic resistant bacteria possess resistance genes which can be transmitted to susceptible strains. These genes may be spread to sensitive microbiota of the milk as well as to consumers gut microbiota. Our results clearly show importance of appropriate and sufficient heating of raw milk before consumption.

Acknowledgments

This work was supported by the Slovak Research and Development Agency under the contracts No. APVV-160171 and Research grant agency MŠVVaŠ SR and SAV VEGA grant 1/0096/17. 


\section{References}

Ačai P, Valík L, Medved’ová A, Rosskopf F (2015) Food Science and Technology International 22: 475-484.

Bianchi DM, Barbaro A, Gallina S, Vitale N, Chiavacci L, Caramelli M, Decastelli L (2013) Food Control 32: 435-439.

Coorevits A, De Jonghe V, Vandroemme J, Reekmans R, Heyrman J, Messens W, De Vos P, Heyndrickx M (2008) Systematic and Applied Microbiology 31: 126-140.

De Silva SASD, Kanugala KANP, Weerakkody NS (2016) Procedia Food Science 6: 92-96.

Do Carmo LS, Souza Dias R, Linardi VR, José de Sena M, Aparecida dos Santos D, Solomakos N, Govaris A, Angelidis AS, Pournaras S, Burriel AR, Kritas SK, Papageorgiou DK (2009) Food Microbiology 26: 865-871.

Ellis KA, Innocent GT, Mihm M, Cripps P, McLean WG, Howard CV, Grove-White D (2007) Journal of Dairy Research 74: 302-310.

Food Standards Australia New Zealand (2009) Microbiological Risk Assessment of Raw Cow Milk 1-119.

Jevinova P, Dudrikova E, Sokol J, Nagy J, Mate D, Pipova M, Cabadaj R (2003) Bulletin-Veterinary Institute in Pulawy 47: 211-216.

Jorgensen HJ, Mathisen T, Løvseth A, Omoe K, Qvale KS, Loncarevic S (2005) FEMS Microbiology Letters 252: 267-272.

Jung WK, Lim JY, Kwon NH, Kim JM, Hong SK, Koo HCh, Kim SH, Park YH (2007) International Journal of Food Microbiology 113: 102-107.
Latorre AA, Van Kessel JAS, Karns JS, Zurakowski MJ, Pradhan AK, Zadoks RN, Boor KJ, Schukken YH (2009) Applied and Environmental Microbiology 75: $1315-1323$.

Mackulak T, Vojs M, Grabic R, Golovko O, Staňová AV, Bírošová L, Medved’ová A, Híveš J, Gál M, Kromka A, Hanusová A (2016) Monatshefte fur Chemie 147: 97-103.

Oliver SP, Boor KJ, Murphy SC, Murinda SE (2009) Foodborne Pathogens and Disease 6: 793-806.

Quigley L, O'Sullivan O, Stanton C, Beresford TP, Ross RP, Fitzgerald GF, Cotter PD (2013) Federation of European Microbiological Societies 37: 664-698.

Regulation EC (2004) Regulation No. 853/2004 of the European Parliament and of the Council of 29 April 2004 laying down specific hygiene rules on the hygiene of foodstuffs, Official Journal of the European Union L 139 47: 206-320.

Teuber M, Perreten V (2000) Acta Veterianaria Scandinavica 93: 75-87.

The Community Summary Report on Trends and Sources of Zoonoses, Zoonotic Agents and Food-borne Outbreaks in the European Union in 2008, EFSA Journal (2010) 8: 1496-1906.

Valík L, Medved'ová A, Bírošová L, Liptáková D, Ondruš L, Šnelcer J (2009) Potravinárstvo 5: 38-43.

Valík L (2013) MPRV SV Available in March 2018: www.mpsr.sk/download.php?fID=7791. 